Jurnal Health Sains: p-ISSN: 2723-4339 e-ISSN: 2548-1398

Vol. 3, No. 1, Januari 2022

\title{
PENGARUH MOTIVASI DAN IMBALAN TERHADAP KEPATUHAN PENGISIAN REKAM MEDIS
}

\author{
M. Tryanza Maulana, Rokiah Kusumapradja, Andry \\ Universitas Esa Unggul, Jakarta, Indonesia \\ Email: mtryanzamaulana@gmail.com,rokiah.kusumapradja@esaunggul.ac.id, \\ andry@esaunggul.ac.id
}

\begin{tabular}{ll}
\hline INFO ARTIKEL & ABSTRAK \\
\hline Diterima & Standar Pelayanan Minimal (SPM), rumah sakit tempat terdapat \\
5 Januari 2022 & informasi mengenai standar pelayanan rekam medis rumah sakit adalah \\
Direvisi & kelengkapan pengisian rekam medis 24 jam setelah selesai pelayanan \\
15 Januari 2022 & dan kelengkapan persetujuan informasi setelah mendapatkan informasi \\
Disetujui & yang jelas memiliki standar 100\%. Penelitian ini bertujuan untuk \\
25 Januari 2022 & menganalisis pengaruh pemahaman tentang rekam medis, sikap, \\
\hline Kata Kunci: & motivasi, imbalan dan desain kerja terhadap kepatuhan dokter dalam \\
kepatuhan; & mengisi rekam medis di RS Insan Permata. Penelitian ini menggunakan \\
pemahaman; & pendekatan kuantitatif dengan sampel penelitian 30 responden. \\
motivasi; sikap; & Pengujian analisis data menggunakan regresi logistik biner. Hasil \\
imbalan; desain & penelitian yang diperoleh ada pengaruh (simultan) pemahaman, \\
pekerjaan & motivasi, sikap, imbalan, dan desain pekerjaan dokter terhadap \\
& kepatuhan pengisian rekam medis. Secara parsial ada pengaruh motivasi \\
& dan imbalan terhadap kepatuhan dokter dalam pengisian rekam medis. \\
& Variabel yang paling mempengaruhi kepatuhan adalah motivasi dan \\
& diikuti oleh imbalan. Sebaiknya pihak RS IP dapat memberikan \\
& pelatihan tentang rekam medis untuk dokter atau perawat.
\end{tabular}

\section{ABSTRACT}

Minimum Service Standard (SPM), the hospital in which there is information about the standard of hospital medical record service is the completeness of filling medical records 24 hours after completion of service and completeness of informed consent after obtaining clear information has a standard of 100\%. This study aims to analyze the influence of understanding about medical records, attitudes, motivations, rewards and work design to the compliance of doctors in filling medical records at Insan Permata Hospital. This study uses a quantitative approach with a research sample of 30 respondents. Data analysis testing using binary logistic regression. The results of the research obtained there is the influence (simultaneous) understanding,

Keywords: motivation, attitude, rewards, and design of the doctor's work to the compliance; understanding; motivation; attitude; rewards; design compliance of medical record filling. Partially there is an influence of motivation and rewards to the doctor's compliance in the filling of medical records. The variable that most affects compliance is motivation and is followed by rewards. It is recommended that IP Hospitals can work provide training on medical records for doctors or nurses.

$\begin{array}{ll}\text { How to cite: } & \text { Maulana. M. Tryanza. et.al (2022) Pengaruh Motivasi dan Imbalan terhadap Kepatuhan Pengisian } \\ & \text { Rekam Medis. Jurnal Health Sains 3(1). https://doi.org/10.46799/jhs.v3i1.393 } \\ \text { E-ISSN: } & 2723-6927 \\ \text { Published by: } & \text { Ridwan Institute }\end{array}$




\section{Pendahuluan}

Rumah sakit merupakan sarana pelayanan kesehatan yang mutlak dibutuhkan oleh segenap lapisan masyarakat dalam upaya peningkatan derajat kesehatan baik individu maupun masyarakat secara keseluruhan. Untuk memenuhi kebutuhan tersebut maka rumah sakit dituntut untuk memberikan pelayanan yang memadai dan memuaskan. Oleh karena itu, rumah sakit harus mampu meningkatkan kualitas pelayanannya, termasuk diantaranya peningkatan kualitas pendokumentasian rekam medis (Solikhah et al., 2010).

Rekam medis terkait erat dengan Standar Pelayanan Rumah Sakit. Rumah sakit harus menyelenggarakan rekam medis yang merupakan bukti tentang proses pelayanan medis yang diberikan kepada pasien. Berdasarkan Keputusan Menteri Kesehatan RI No.129/Menkes/SK/II/2008 tentang Standar Pelayanan Minimal (SPM), rumah sakit yang didalamnya terdapat informasi mengenai standar pelayanan rekam medis rumah sakit yaitu kelengkapan pengisian rekam medis 24 jam setelah selesai pelayanan dan kelengkapan informed consent setelah mendapatkan informasi yang jelas memiliki standar yaitu $100 \%$.

Dalam peraturan Menteri Kesehatan Republik Indonesia No.269/Menkes/PER/III/2008, disebutkan ketentuan minimal yang harus di lengkapi oleh petugas kesehatan (terutama dokter dalam pengisian pencatatan rekam medis rawat inap). Sekurang - kurangnya memuat 13 (tiga belas) butir (aspek pengisian) yang wajib dilengkapi yaitu : (1) identitas pasien (2) tanggal dan waktu (3) hasil anamnese, mencakup sekurang-kurangnya keluhan dan riwayat penyakit (4) hasil pemeriksaan fisik dan penunjang medik (5) diagnosis (6) rencana penatalaksanaan (7) pengobatan dan/atau tindakan (8) persetujuan tindakan bila diperlukan (9) catatan observasi klinis dan hasil pengobatan (10) ringkasan pulang (discharge summary) (11) nama dan tanda tangan dokter, dokter gigi, atau tenaga kesehatan tertentu yang memberikan pelayanan Kesehatan pelayanan lain yang dilakukan oleh tenaga kesehatan tertentu untuk pasien kasus gigi di lengkapi dengan odontogram klinik.

Menurut Pasal 46 ayat (1) UU RI No. 29 Tahun 2004 tentang praktik kedokteran menyatakan bahwa "rekam medis merupakan berkas yang berisi catatan dan dokumen yang terdiri dari identitas pasien, pemeriksaan, pengobatan, tindakan dan pelayanan lain yang telah diberikan kepada pasien". Dan yang di maksud dengan "petugas" adalah dokter atau dokter gigi atau tenaga kesehatan lain yang memberikan pelayanan kesehatan langsung kepada pasien. Bila yang bersangkutan dengan sengaja tidak membuat rekam medis sebagaimana yang dimaksud dalam pasal 79, maka dokter atau dokter gigi dapat dipidana kurungan paling lama 1 (satu) tahun atau denda paling banyak RP.50.0000.000,00,--

Undang-Undang Sistem Jaminan Sosial Nasional (SJSN) telah diberlakukan sejak 1 Januari 2014, Undang-Undang tersebut berpengaruh terhadap konsep layanan kesehatan di Indonesia. Sebagai penyedia layanan kesehatan, rumah sakit mau tidak mau harus mengikuti perubahan signifikan dalam era Jaminan Kesehatan Nasional (JKN). Salah satunya adalah perubahan proses administrasi dalam melakukan klaim biaya pelayanan pasien kepada Badan Penyelenggara Jaminan Sosial (BPJS). BPJS mewajibkan pengisian dokumen rekam medis secara lengkap untuk memproses klaim biaya pasien. Tidak sedikit rumah sakit mengalami masalah administrasi berupa dokumen rekam medis yang tidak lengkap, terlebih apabila rumah sakit masih menggunakan sistem dokumen rekaman medis berbasis kertas.

Rumah Sakit Insan Permata merupakan Rumah Sakit tipe $\mathrm{C}$ dengan jumlah tempat tidur sebanyak 74 tempat tidur. Rumah Sakit Insan Permata terletak di daerah Serpong 
Utara dengan kondisi lingkungan sekitar yang padat penduduk. Pelayanan kesehatan yang tersedia di Rumah Sakit Insan Permata bagi peserta JKN yaitu pelayanan rawat jalan, rawat inap dan unit gawat darurat. Pelayanan rawat jalan yang ada di Rumah Sakit Insan Permata yaitu Poli Internis, Poli Obgyn, Poli Anak, Poli Bedah, Poli THT-KL, Poli Syaraf, Poli Jantung, Poli Kulit dan Kelamin, Poli Paru, Poli Gigi Spesialis, Poli Gigi, Poli KIA dan Poli Rehabilitasi Medik dengan rata-rata kunjungan pasien per hari 100 pasien. Jaminan pembayaran yang dapat dilakukan di Rumah Sakit Insan Permata yaitu jaminan pribadi, jaminan asuransi dan jaminan BPJS. Untuk mendapatkan pelayanan kesehatan maka peserta JKN harus melakukan pendaftaran dengan membawa berkas pendukung seperti fotocopy KTP, fotocopy Kartu BPJS, fotocopy Kartu Keluarga, Fotocopy Akte Kelahiran (bagi peserta dengan usia dibawah 17 tahun), surat kontrol (bagi pasien yang kronis, post rawat inap dan fisioterapi) dan surat rujukan dari FKTP. Setelah pasien memberikan berkas pendukung tersebut kemudian pasien menunggu di poli dan mendapatkan pelayanan kesehatan. Setelah mendapatkan pelayanan kesehatan oleh Dokter, pasien menunggu obat di bagian farmasi dan melakukan verifikasi berkas di kasir. Jika berkas lengkap maka pasien dapat mengambil obat dan pasien diperbolehkan pulang.

Pengajuan klaim Rumah Sakit Insan Permata kepada BPJS Kesehatan mengalami keterlambatan selama 19 bulan yaitu 11 bulan pada tahun 2019 dan 8 bulan pada tahun 2020. Rata-rata keterlambatan mulai dari waktu 3 hari sampai 23 hari dengan jumlah berkas yang tidak lengkap paling sedikit berjumlah 8 berkas di rawat inap dan 25 berkas di rawat jalan. Serta paling banyak 17 berkas di rawat inap dan 256 berkas di rawat jalan. Pengajuan klaim di Rumah Sakit Insan Permata masih ditemukan beberapa kendala. Terpenuhinya kelengkapan dokumen yang dipersyaratkan memudahkan pihak Casemix untuk lebih cepat dalam proses verifikasi berkas dan penginputan kedalam aplikasi EKlaim sehingga pengajuan klaim kepada BPJS Kesehatan dapat terpenuhi tepat waktu pada tanggal 5 di awal bulan berikutnya.

Pengajuan klaim yang diajukan oleh Rumah Sakit Insan Permata masih mengalami keterlambatan dari tanggal jatuh tempo yang telah disepakati dengan oleh pihak Rumah Sakit dengan pihak BPJS Kesehatan.

Jika Rumah Sakit mengalami keterlambatan dalam pengajuan klaim BPJS Kesehatan maka kegiatan operasional di Rumah Sakit akan mengalami kendala dan terhambat dalam pelayanan medis. Salah satu kegiatan operasional Rumah Sakit yang dapat mengalami kendala antara lain ketersediaan obat, pengadaan alat medis dan tertundanya pembayaran insentif pegawai rumah sakit.

Patuh adalah suka menurut perintah, taat pada perintah, sedangkan kepatuhan adalah perilaku sesuai aturan dan berdisiplin (Pranoto, 2017). Menururt Sunarti kepatuhan praktisi kesehatan dalam melengkapi informasi medis sesuai dengan jenis pelayanan yang telah diberikan kepada pasien merupakan kunci terlaksananya kegunaan rekam medis di atas. Namun, masih banyak dokter dan perawat yang enggan mengisi rekam medis dengan benar karena alasan terbatasnya waktu atau anggapan bahwa rekam medik hanya penting untuk keperluan administrasi rumah sakit (Dewi, 2015).

Pemahaman, seseorang dikatakan patuh apabila orang tersebut dapat memahami dan menjalankan aturan yang berlaku. Dokter akan patuh jika menyadari, memahami dan melakukan pengisian dokumen rekam medis.

Motivasi merupakan konsep yang digunakan untuk menggambarkan dorongandorongan yang timbul pada atau di dalam seorang individu yang menggerakkan dan mengarahkan individu (Gibson, 2008).

Sikap merupakan determinan perilaku sebab yang berkaitan dengan persepsi, 
kepribadian, dan motivasi. Sebuah sikap adalah perasaan positif atau negatif atau keadaan mental yang selalu disiapkan, dipelajari, dan diatur melalui pengalaman yang memberikan pengaruh khusus pada respon seseorang terhadap orang, obyekobyek dan keadaan (Gibson, 2008).

Imbalan diharapkan bahwa setiap paket imbalan sebaiknya cukup memuaskan kebutuhan dasar (seperti makanan, tempat tinggal, pakaian), dipandang wajar, dan berorientasi pada individu (Gibson, 2008)

Desain kerja adalah fungsi penetapan kegiatan-kegiatan kerja seorang individu atau kelompok karyawan secara organisasional (Subkhi, 2012)

Pada dasarnya rekam medis merupakan salah satu bagian penting dalam pelayanan kesehatan di rumah sakit. Keputusan medis dokter yang diambil oleh seorang dokter berdasarkan diagnosa yang dibuat, akan sangat mempengaruhi tindakan terhadap pasien baik dalam pengobatan atau bahkan tindakan yang akan diambil. Suatu diagnosa yang akurat didasari oleh anamnesa, pemeriksaan fisik, pemeriksaan penunjang dan ditulis dalam berkas rekam medis. Berkas rekam medis berisi semua catatan atau rekaman tindakan kepada pasien selama mendapat perawatan di Rumah Sakit. Berkas rekam medis ini sebagai bukti tindakan dokter terhadap pasien, sehingga bila terjadi gugatan dari pasien terhadap dokter atas pengobatan atau tindakan yang telah dilakukan oleh dokter, dokumen tersebut dapat menjadi alat bukti. Kelengkapan data pada berkas rekam medis juga bermanfaat bagi dokter yang bersangkutan karena sebagai bukti otentik pelayanan dokter terhadap pasien sehingga bila ada tuntutan, data pada rekam medis dapat sebagai bukti.

Hal ini didukung dengan hasil penelitian (Anggraini et al., 2007) kepatuhan praktisi kesehatan dalam melengkapi informasi medis sesuai dengan jenis pelayanan yang telah diberikan kepada pasien merupakan kunci terlaksananya kegunaan rekam medis. Namun kenyataanya masih banyak dokter dan perawat yang tidak mengisi rekam medis dengan benar karena alasan terbatasnya waktu dan anggapan bahwa hanya penting untuk keperluan administrasi rumah sakit. Dalam penelitian ini mencatat dari 100 sampel berkas yang diambilnya untuk dianalisis sebanyak 34,1\% berkas tidak diisi dengan lengkap, 59,3\% tidak dikembalikan tepat waktu dan $56,1 \%$ tidak disi secara tepat.

(Solikhah et al., 2010) di Rumah Sakit PKU Muhammadiyah menunjukkan ketidaklengkapan rekam medis yang masih tinggi di RS tersebut antara lain waktu yang digunakan dokter untuk mengisi berkas rekam medis sangat terbatas karena banyaknya pasien sehingga dokter berusaha untuk memberikan pelayanan dengan cepat, desain kerja dokter yang tinggi, kurangnya kerjasama antar perawat dan petugas rekam medis, kurangnya kesadaran dokter akan pentingnya kelengkapan pengisian berkas rekam medis.

Berdasarkan hasil wawancara pendahuluan serta telaah terhadap 20 berkas rekam medis diambil dan di periksa secara acak oleh penulis sebelumnya di RS Insan Permata bahwa proses pengisian dan penggunaan rekam medis sebagai sistem informasi manajemen untuk meningkatkan mutu dan pengembangan rumah sakit masih belum berjalan dengan baik. Hal ini disebabkan tiga masalah pokok, yaitu: 1 . Dari 20 berkas rekam medis, ada 13 berkas (65\%) yang data rekam medisnya belum terisi secara lengkap dan akurat seperti anamnesis dan rencana penatalaksanaan serta pengobatan atau tindakan yang akan dilakukan kepada pasien nanti, kolom yang kosong pada formulir yang seharusnya diisi oleh dokter untuk pasien rawat inap maupun rawat jalan serta tulisan yang tidak jelas sehingga sulit di baca dan sebagian dokter tidak menuliskan namanya walaupun ada tanda tangannya. 2 . 
Dari 5 orang manajer rumah sakit yang diwawancarai, ada 2 orang (40\%) yang menyatakan bahwa kurangnya sosialisasi untuk pengisian formulir rekam medis kepada dokter yang merawat pasiennya sehingga kurang mendorong dan mendukung perkembangan yang optimal rekam medis di rumah sakit. Dan 3. Dari 6 orang pengelola rekam medis yang diwawancarai, ada 4 orang (67\%) masih belum dapat mengevaluasi dan memahami dalam kelengkapan dan kualitas rekam medis secara baik dan benar.

Lalu faktor motivasi, dari 10 orang dokter yang diwawancarai, diketahui ada 7 orang $(70 \%)$ mengatakan bahwa rumah sakit tidak pernah menyediakan secara khusus pelatihan tentang manajemen informasi dan rekam medis, sehingga dokter tidak termotivasi untuk memperbaiki cara pengisian rekam medis. Kemudian faktor imbalan, ada 6 orang dokter (60\%) mengatakan bahwa dalam mengisi rekam medis baik lengkap ataupun tidak lengkap, maka tidak akan mempengaruhi kenaikan pangkat, bonus ataupun mutasi kerja. Dari faktor sikap ada 6 orang dokter (60\%) mengatakan merasa waktunya terbatas karena banyaknya jumlah pasien serta kurang tegasnya sikap dari pihak rumah sakit kepada dokter yang telat dalam pengembalian dan kurang lengkap dalam pengisian berkas rekam medis, baik itu teguran dari pihak komite medik maupun direktur rumah sakit. Dan yang terakhir pada faktor desain kerja, diketahui bahwa ada 5 orang dokter $(50 \%)$ mengatakan belum adanya kebijakan yang terarah dan terencana dari rumah sakit yang mendukung kelengkapan pengisian rekam medis pasien.

Berdasarkan uraian latar belakang diatas maka dari itu penulis tertarik untuk melakukan penelitian tentang "Pengaruh Pemahaman, Motivasi, Sikap, Imbalan, Dan Desain Kerja Dokter Terhadap Kepatuhan Pengisian Rekam Medis Di RS Insan Permata" dengan harapan dapat memberikan solusi terhadap permasalahan yang dihadapi rumah sakit.

Tujuan Penelitian untuk menganalisis pengaruh pemahaman tentang rekam medis, sikap, motivasi, imbalan dan desain kerja terhadap kepatuhan dokter dalam pengisian rekam medis di RS Insan Permata.

Adapun hipotesis yang akan dibuktikan dalam penelitian ini adalah :

H1: Ada pengaruh pemahaman tentang Rekam Medis, sikap, motivasi, imbalan dan desain kerja terhadap kepatuhan dokter dalam pengisian rekam medis di RS Insan Permata

H2: Tidak ada pengaruh pemahaman dokter terhadap kepatuhan pengisian rekam medis

H3: Ada pengaruh motivasi dokter terhadap kepatuhan pengisian rekam medis

H4: Tidak ada pengaruh sikap dokter terhadap kepatuhan pengisian rekam medis

H5: Ada pengaruh imbalan dokter terhadap kepatuhan pengisian rekam medis

H6: Tidak ada pengaruh desain kerja dokter terhadap kepatuhan pengisian rekam medis.

\section{Metode Penelitian}

Pada penelitian ini, peneliti menggunakan jenis penelitian deskriptif dengan pendekatan kuantitatif. Penelitian deskriptif yaitu penelitian yang dilakukan untuk mengetahui nilai variabel mandiri, baik satu variabel atau lebih (independent) tanpa membuat perbandingan, atau menghubungkan dengan variabel yang lain (Sugiyono, 2017). Penelitian deskriptif ini digunakan untuk menggambarkan kepatuhan dalam pengisian berkas rekam medis di RS Insan Permata yang meliputi faktor individu (pemahaman), faktor psikologis (motivasi dan sikap), dan faktor organisasi (imbalan dan desain kerja) yang dilakukan oleh dokter di RS Insan Permata. Populasi dalam penelitian ini adalah seluruh dokter RS Insan Permata. Jumlah 
populasi dalam penelitian ini sudah diketahui berdasarkan data jumlah dokter RS Insan Permata adalah 30 orang. Jumlah sampel yang diambil dalam penelitian ini adalah 30 orang. Tempat penelitian dilakukan di RS Insan Permata yang beralamat di Jl. Bhayangkara 1, No. 68 Kelurahan Paku Jaya Kecamatan Serpong Utara Kota Tangerang
Selatan Penelitian ini dilakukan pada bulan April tahun 2021. Pada penelitian ini, teknik analisis data yang digunakan adalah regresi logistic binary. Total nilai indeks dengan menggunakan kriteria 3 kotak (Three-box Method).

\section{Hasil dan Pembahasan}

Tabel 1

Distribusi Frekuensi Variabel

\begin{tabular}{lcc}
\hline \multicolumn{1}{c}{ Karakteristik } & Jumlah (n) & Persentase (\%) \\
\hline Pemahaman & 5 & \\
$\quad$ Tidak & 25 & 16,7 \\
Ya & 6 & 83,3 \\
\hline Motivasi & 24 & 20,0 \\
$\quad$ Rendah & & 80,0 \\
Tinggi & 7 & \\
\hline Sikap & 23 & 23,3 \\
Rendah & & 76,7 \\
$\quad$ Tinggi & 8 & \\
\hline Imbalan & 22 & 26,7 \\
$\quad$ Rendah & & 73,3 \\
Tinggi & 5 & 16,7 \\
Desain Kerja & 25 & 83,3 \\
Rendah & & \\
Tinggi & 11 & 36,7 \\
\hline Kepatuhan & 19 & 63,3 \\
\hline Tidak & &
\end{tabular}

Berdasarkan tabel 1 diatas diketahui bahwa mayoritas responden memiliki pemahaman terhadap pengisian rekam medis yaitu sebanyak 83,3\%. Memiliki motivasi tinggi sebanyak $80 \%$, memiliki sikap yang positif sebanyak $76,7 \%$, mendapat imbalan yang tinggi $73,3 \%$, desain kerja yang tinggi $83,3 \%$ dan sebagian besar responden patuh sebanyak $63,3 \%$.

Tabel 2

Hasil Uji Model Regresi

95\%

C1.for.EXP(B)

\begin{tabular}{lcccccccc}
\hline & B & S.E & Wald & df & Sig. & $\operatorname{Exp}(\mathbf{B})$ & Lower & Upper \\
\hline Pemahaman & 2.234 & 1.807 & 1.527 & 1 & .216 & 9.333 & .270 & 322.407 \\
\hline Motivasi & 3.524 & 1.700 & 4.295 & 1 & .038 & 33.925 & 1.211 & 950.551 \\
\hline Sikap & 1.868 & 2.113 & .782 & 1 & .377 & 6.478 & .103 & 407.285 \\
\hline Imbalan & 3.027 & 1.452 & 4.347 & 1 & .037 & 20.644 & 1.199 & 355.499 \\
\hline Desain Kerja & 1.657 & 2.275 & .531 & 1 & .466 & 5.243 & .061 & 452.811 \\
\hline Constant & -8.935 & 3.638 & 6.030 & 1 & .014 & .000 & & \\
\hline
\end{tabular}

Berdasarkan tabel 2 di atas diketahui bahwa variabel yang paling dominan

berpengaruh terhadap kepatuhan yaitu variabel motivasi dengan nilai $\mathrm{OR}$ sebesar 
33,925 kemudian diikuti oleh variabel imbalan yaitu sebesar 20,644.

Tabel 3

Hasil Uji Kelayakan Model dan Simultan

\begin{tabular}{llrrrr}
\hline & & Chi-square & df & \multicolumn{1}{c}{ Sig. } & \\
\hline Step 1 & Step & 23.031 & 5 & .000 \\
\cline { 2 - 5 } & Block & 23.031 & 5 & .000 \\
\cline { 2 - 5 } & Model & 23.031 & 5 & .000 \\
\hline
\end{tabular}

Berdasarkan tabel 3 diketahui nilai Chi Square Model Omnibus Test sebesar 23,031 dengan df sebesar 5 dan $\mathrm{p}$ value (sig.) sebesar 0,000 sehingga hasil ini signifikan atau dengan kata lain sudah memenuhi kriteria goodness of fit test. Dan diperoleh nilai sig. sebesar 0,000 karena nilai ini lebih kecil dari 0,05 , maka dapat disimpulkan bahwa pemahaman dokter tentang rekam medis, motivasi, sikap, imbalan dan desain kerja dokter secara simultan berpengaruh terhadap kepatuhan pengisian rekam medis.

a. Hasil Pengujian Hipotesis

Hasil pengujian terhadap model penelitian dapat digambarkan sebagai berikut:

Tabel 4

Pengujian Hipotesis Model Penelitian

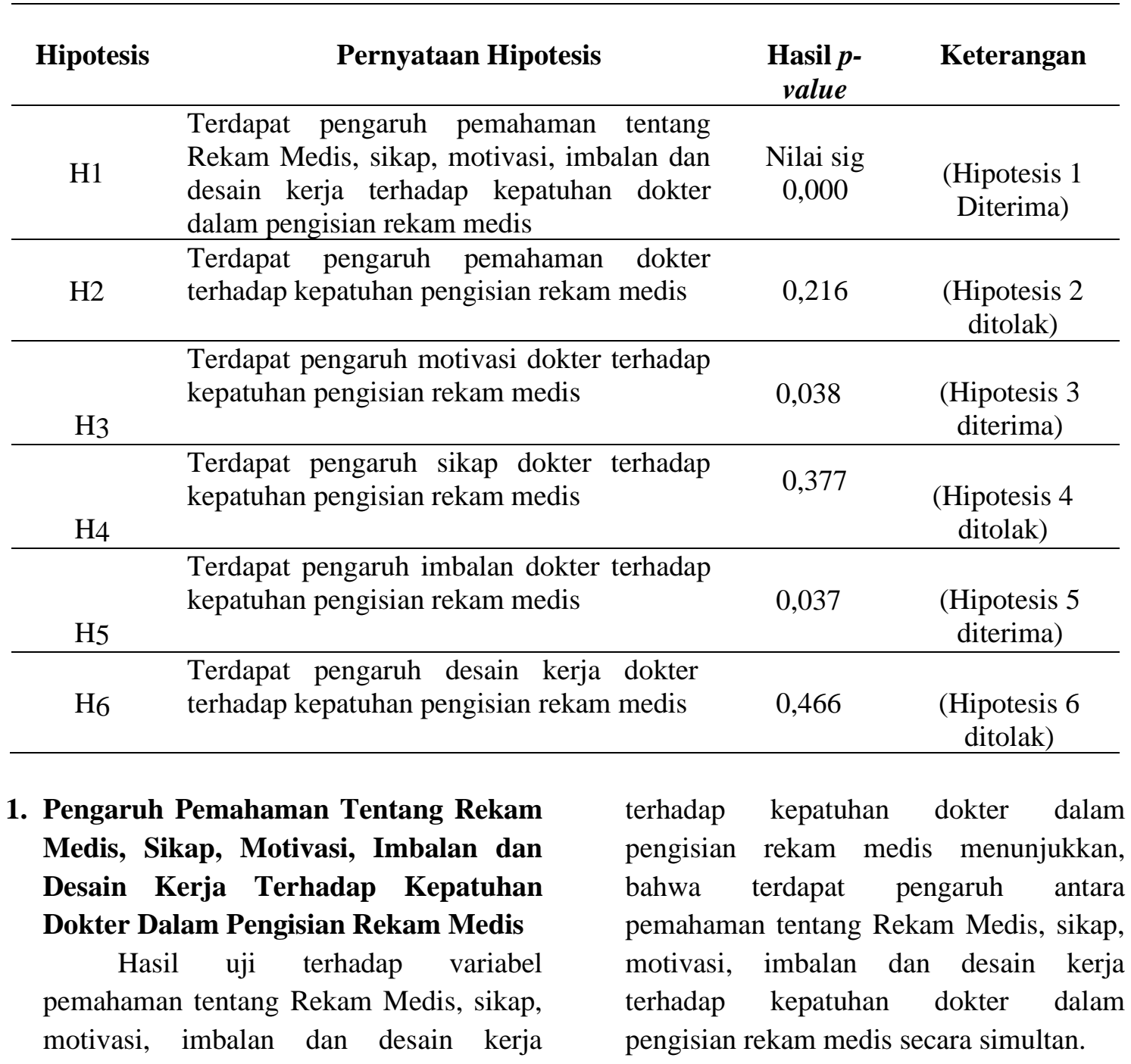


Pemahaman tentang rekam medis menurut (Huffman, 1994), yaitu catatan atau rekaman berisi tentang who (siapa), what (apa), why (mengapa), when (kapan) dan how (bagaimana) pelayanan kesehatan yang diberikan pada pasien sewaktu masa perawatan yang berisi pemahaman tentang pasien dan pelayanan kesehatan yang didapat serta memuat informasi untuk mengidentifikasi pasien, diagnosa penyakit dan pengobatan serta mencatat hasilnya. Menurut LL. Thursione yang dikutip oleh (Ahmadi, 2009) menyatakan, Sikap sebagai tingkatan kecenderungan yang bersifat positif atau negatif yang berhubungan dengan objek psikologi. (Engeser et al., 2009) menerangkan bahwa motivasi kerja adalah pemberian daya penggerak yang menciptakan kegairahan kerja seseorang, agar mereka mau bekerja sama, bekerja efektif dan terintegrasi dengan segala daya upayanya untuk mencapai kepuasan. Menurut (Dessler, 2004) kompensasi karyawan adalah setiap bentuk pembayaran atau imbalan yang diberikan kepada karyawan dan timbul dari diperkerjannya karyawan itu. Desain pekerjaan adalah cara dimana tugas-tugas digabungkan untuk membentuk suatu pekerjaan yang lengkap (Stephen \& Timothy, 2014). Dan Kepatuhan adalah fenomena yang mirip dengan penyesuaian diri. Perbedaannya terletak pada segi pengaruh legitimasi (kebalikan dengan paksaan atau tekanan sosial), dan selalu terdapat suatu individu, yakni pemegang otoritas (Boeree, 2008).

Hasil penelitian ini mendukung penelitian sebelumnya yang telah dilakukan oleh (Ahmad, 2020), menyatakan bahwa pengetahuan, sikap dan motivasi secara bersama-sama berpengaruh terhadap kepatuhan. Hal ini sejalan dengan penelitian yang telah dilakukan oleh (I. S. Rahayu et al., 2021) menunjukkan bahwa berpengaruh positif pemahaman pajak terhadap kepatuhan wajib pajak hotel. Sama halnya dengan penelitian yang dilakukan oleh (Tandy, 2018) didapatkan hasil bahwa ada hubungan yang erat dan positif antara imbalan dengan kepatuhan pengisisan berkas rekam medis di RSD Kalisat Jember.

Dengan adanya pemahaman yang baik tentang rekam medis, sikap yang baik, memiliki motivasi, imbalan yang memadai dan desain kerja yang tinggi maka secara bersama-sama maka dapat berpengaruh terhadap kepatuhan dokter dalam pengisian rekam medis.

\section{Pengaruh Pemahaman Dokter Terhadap Kepatuhan Pengisian Rekam Medis}

Hasil uji terhadap variabel pemahaman dokter terhadap kepatuhan pengisian rekam medis menunjukkan, bahwa tidak terdapat pengaruh antara pemahaman terhadap kepatuhan, sehingga hipotesis ditolak.

Menurut IFHRO (International Federation Health Record Organization) adalah a health record contains all information about a patient, his illness and treatment and the end entries in it are recorded in the order in wich event of care occours, artinya pemahaman dokter dalam mengisi rekam medis yang berisi semua informasi mengenai pasien, penyakit, pengobatan dan rekaman yang didalamnya sesuai dengan urutan pelayanan/perawatan). Kepatuhan adalah kepatuhan adalah memenuhi permintaan orang lain, didefinisikan sebagai suatu tindakan atau perbuatan yang dilakukan berdasarkan keinginan orang lain atau melakukan apa-apa yang diminta oleh orang lain, kepatuhan mengacu pada perilaku yang terjadi sebagai respons terhadap permintaan langsung dan berasal dari pihak lain (Taylor et al., 2009). 
Hasil penelitian ini tidak sejalan dengan penelitian sebelumnya yang dilakukan oleh (Adiasa, 2013) menyatakan bahwa pemahaman tentang peraturan perpajakan berpengaruh terhadap kepatuhan wajib pajak. Sama halnya dengan penelitian yang dilakukan oleh $(\mathrm{N}$. D. Rahayu, 2015) menunjukkan bahwa berpengaruh positif pemahaman pajak terhadap kepatuhan wajib pajak hotel.

Adanya sosialisasi tentang rekam medis, kegunaannya serta pentingnya rekam medis dapat membuat petugas lebih patuh dalam pengisian rekam medis. Karena ia sudah paham akan pentingnya pengisian rekam medis ini. Dengan adanya pemahaman yang baik maka akan mempengaruhi kepatuhan seseorang, hal ini berhubungan dengan pengisian rekam medis. Tetapi hasil penelitian ini menunjukkan bahwa tidak terdapat pengaruh antara pemahaman terhadap kepatuhan. Hal ini dapat disebabkan walaupun dokter paham dengan pengisian rekam medis ini tetapi terkadang karena kondisi keadaan sehingga mempengaruhi kepatuhan dalam mengisi kelengkapan rekam medis, seperti dokter yang terburuburu dalam pengisian rekam medis disebabkan jadwal yang dekat dengan jam praktek di poli karena sudah banyaknya pasien yang sudah menunggu atau bisa dikarenakan ada jam praktek di rumah sakit lainnya. Sehingga hal ini menyebabkan tidak sesuainya teori dengan hasil penelitian ini.

3. Pengaruh Motivasi Dokter Terhadap Kepatuhan Pengisian Rekam Medis

Hasil uji terhadap variabel motivasi dokter terhadap kepatuhan pengisian rekam medis menunjukkan bahwa ada pengaruh antara motivasi dokter terhadap kepatuhan pengisian rekam medis.

Motivasi adalah dorongandorongan yang timbul pada atau di dalam seorang individu yang menggerakkan dan mengarahkan individu (Gibson, 2008). Motivasi merupakan pemberian daya gerak yang menciptakan kegairahan kerja seseorang, agar mereka mau bekerja sama, bekerja efektif dan dan terintegrasi dengan segala daya upayanya. Sedangkan kepatuhan adalah suatu tindakan atau perbuatan yang dilakukan berdasarkan keinginan orang lain atau melakukan apaapa yang diminta oleh orang lain, kepatuhan mengacu pada perilaku yang terjadi sebagai respons terhadap permintaan langsung dan berasal dari pihak lain (Taylor et al., 2009).

Hasil penelitian ini juga mendukung penelitian sebelumnya yang dilakukan oleh (Ahmad, 2020), menyatakan bahwa motivasi berpengaruh signifikan terhadap kepatuhan penulisan diagnose pada resume medis pasien. Sama halnya dengan penelitian yang dilakukan oleh (Rakhmaningrum, 2016) menyatakan bahwa ada hubungan motivasi dari pimpinan terhadap kepatuhan. Begitu pula dengan penelitian yang telah dilakukan oleh (Agustini \& Mulya, 2019) menyatakan bahwa ada hubungan motivasi kerja perawat dengan kepatuhan pendokumentasian flowsheet.

Motivasi menjadi sebuah alasan yang mendasari sebuah perbuatan yang dilakukan oleh seorang individu. Dengan adanya motivasi dari dalam diri seseorang maka seseorang tersebut akan terdorong untuk untuk menghasilkan pekerjaan yang memiliki kualitas yang tinggi, dalam hal ini berkaitan dengan motivasi untuk mematuhi pengisian resume medis. Dokter memiliki motivasi kerja yang baik lebih patuh dalam melakukan pengisian rekam medis karena dengan adanya motivasi yang kuat dalam diri seorang dokter dalam melakukan dokumentasi dengan baik maka intervensi yang akan dilakukan kepada klien akan lebih terarah dan sesuai dengan kebutuhan klien. 


\section{Pengaruh Sikap Dokter Terhadap Kepatuhan Pengisian Rekam Medis}

Hasil uji terhadap variabel sikap dokter terhadap kepatuhan pengisian rekam medis menunjukkan bahwa tidak ada pengaruh antara sikap dokter terhadap kepatuhan pengisian rekam medis, sehingga hipotesis ditolak.

Sikap menurut La Pierre dalam (Mangkunegara, 2005) sikap diartikan sebagai suatu pola atau perilaku kesiapan seseorang agar bisa menyesuaikan diri atau mungkin disebut sebagai adaptasi. Dimana adaptasi itu bisa dilakukan dengan cara rumit ataupun sederhana. Sikap juga bentuk respon dari stimulant sosial yang sudah terkondisikan. Menurut (Blass, 1999) mengungkapkan bahwa kepatuhan adalah menerima perintah-perintah dari orang lain. Kepatuhan dapat terjadi dalam bentuk apapun, selama individu tersebut menunjukkan perilaku taat terhadap sesuatu atau seseorang.

Hasil penelitian ini tidak sejalan dengan penelitian yang dilakukan oleh (Tandy, 2018), menyatakan bahwa ada hubungan yang erat antara sikap dengan kepatuhan pengisian berkas rekam medis di RSD Kalisat Jember. Dan (Lubis, 2018) menyatakan bahwa terdapat pengaruh sikap petugas terhadap kelengkapan formulir pemeriksaan pasien rawat inap.

Seseorang yang mempunyai sikap positif terhadap sesuatu maka dapat mempengaruhi agar dapat melakukan sesuatu, niat yang kuat untuk melakukan sesuatu akan mempengaruhi seseorang dalam berprilaku dalam hal ini kepatuhan dalam pengisian berkas rekam medis.Semakin baik sikap dokter selama bekerja maka akan semakin tinggi kepatuhannya dalam pengisian berkas rekam medis. Tetapi hasil penelitian ini sikap dokter tidak mempengaruhi kepatuhan dalam pengisian rekam medis. Hal ini dapat di sebabkan karena walaupun seseorang sudah memiliki sikap yang positif terhadap sesuatu tetapi karena pengaruh kondisi di tempat bekerja yang tidak memungkinkan seperti jumlah pasien yang mengantri sudah banyak sehingga mempengaruhi dokter pada saat pengisian rekam medis tersebut, ataupun pada pasien rawat inap, dokter akan menulis rekam medisnya pada saat selesai visite, karena terburu-buru sehingga mempengaruhi kelengkapan berkas rekam medis tersebut. Sudah menjadi hal yang biasa bila berkas rekam medis yang tidak lengkap pengisiannya maka akan dilengkapi dulu sebelum mengembalikan ke unit rekam mediknya, sehingga dokter akan bersikap biasa saja apabila pengisian rekam medis belum lengkap. Oleh karena itu hal ini akan mempengaruhi kepatuhan dalam pengisian rekam medis tersebut. Sehingga sikap tidak berpengaruh terhadap kepatuhan pengisian rekam medis.

\section{Pengaruh Imbalan Dokter Terhadap} Kepatuhan Pengisian Rekam Medis

Hasil uji terhadap variabel imbalan dokter terhadap kepatuhan pengisian rekam medis menunjukkan bahwa ada pengaruh antara imbalan dokter terhadap kepatuhan pengisian rekam medis.

(Newman \& Milkovich, 2008) menjelaskan bahwa pay sistems are designed efficiency (performance driven, total quality, customer focus, cost control), equity and compliance (Sistem imbalan didesain dan dikelola untuk memastikan tercapainya tujuan. Tujuan yang paling utama dalam pemberian imbalan adalah efisiensi, keadilan dan pemenuhan). Pengembangan tujuan pembayaran imbalan sangat tergantung pada masingmasing perusahaan dan jenis usaha. Menurut Dessler (2004) kompensasi karyawan (imbalan) adalah setiap bentuk pembayaran atau imbalan yang diberikan kepada karyawan dan timbul dari dipekerjakanya karyawan itu. (Nugroho, 
2010), menyebutkan bahwa kepatuhan adalah perilaku individu (misalnya: minum obat, mematuhi diet, atau melakukan perubahan gaya hidup) sesuai anjuran yang diberikan. Tingkat kepatuhan dapat dimulai dari tindak mengindahkan setiap aspek anjuran hingga mematuhi rencana.

Hasil penelitian ini sama halnya dengan penelitian yang dilakukan oleh (Istirochah, 2021) bahwa kepatuhan dokter yang bertanggung jawab atas rekam medis di RSUD Boyolali dipengaruhi oleh insentif. Sejalan dengan penelitian Penelitian yang telah dilakukan oleh (Tandy, 2018) didapatkan hasil bahwa ada hubungan yang erat dan positif antara imbalan dengan kepatuhan pengisisan berkas rekam medis di RSD Kalisat Jember. Tetapi berbeda dengan penelitian yang telah dilakukan oleh (Tutik, 2019) yang menyatakan bahwa tidak ada hubungan imbalan yang di terima perawat dengan kepatuhan pendokumentasian flowsheet di Rumah Sakit TK II Pelamonia Makassar.

Tanggung jawab, kewajiban dan tuntutan dalam suatu pekerjaan juga mempengaruhi kepatuhan seseorang dengan adanya imbalan yang diterima cukup maka akan membuat semangat dalam bekerja. Jika balas jasa yang diterima dokter semakin besar berarti jabatannya semakin tinggi, statusnya semakin baik, dan pemenuhan kebutuhan yang dinikmatinya semakin banyak pula. Dengan demikian, kinerjanya juga semakin baik dalam hal ini berkaitan dengan pengisian rekam medis. Dengan adanya imbalan yang didapat dokter maka dapat memberikan dorongan untuk berperilaku lebih baik lagi dalam hal ini hubungannya dengan berprilaku untuk patuh dalam pengisian berkas rekam medis.

\section{Pengaruh Desain Kerja Dokter Terhadap Kepatuhan Pengisian Rekam Medis}

Hasil uji terhadap variabel desain kerja dokter terhadap kepatuhan pengisian rekam medis menunjukkan bahwa tidak ada pengaruh antara desain kerja dokter terhadap kepatuhan pengisian rekam medis. Sehingga hipotesis ditolak.

Desain pekerjaan adalah cara dimana tugas-tugas digabungkan untuk membentuk suatu pekerjaan yang lengkap (Robbins et al., 2009). Desain pekerjaan adalah proses menentukan tugas-tugas spesifik untuk dikerjakan, metode yang dipakai dalam menjalankan tugas dan cara pekerjaan yang bersangkutan berhubungan dengan pekerjaan lain dalam organisasi (Mondy, 2008). Kepatuhan adalah fenomena yang mirip dengan penyesuaian diri. Perbedaannya terletak pada segi pengaruh legitimasi (kebalikan dengan paksaan atau tekanan sosial), dan selalu terdapat suatu individu, yakni pemegang otoritas (Boeree, 2008).

Hasil penelitian ini tidak sesuai dengan penelitian yang dilakukan oleh (Gufron et al., 2018) yang menyatakan bahwa terdapat pengaruh langsung positif desain kerja terhadap produktivitas.

Seharusnya dengan adanya penyusunan desain kerja ini dapat membantu dalam menjelaskan pekerjaan apa yang harus dikerjakan, bagaimana menyelesaikan pekerjaan tersebut berapa banyak pekerjaan yang harus dilakukan dan bagaimana ketentuan yang harus dijalankan sehingga pekerjaan dapat diselesaikan karena semua terarah dengan baik. Tetapi pada penelitian ini desain kerja tidak mempengaruhi kepatuhan dalam pengisian rekam medis, hal ini dapat disebabkan karena pihak manajemen di RS Insan Permata belum ada pemberian sanksi yang tegas tentang kelengkapan rekam medis, sehingga masih ada 
beberapa dokter yang tidak segera melengkapi berkas rekam medisnya walaupun desain kerja yang sudah dibuat telah disusun dengan baik.

\section{Kesimpulan}

Berdasarkan hasil dan pembahasan tentang pengaruh pemahaman, motivasi, sikap, imbalan, dan desain kerja dokter terhadap kepatuhan pengisian rekam medis di RS Insan Permata, maka dapat diambil kesimpulan gambaran karakteristik responden pada penelitian ini adalah mayoritas responden berumur >40 tahun sebanyak $43,3 \%$, berjenis kelamin perempuan sebanyak $60 \%$, pendidikan terakhir sebagai dokter spesialis sebanyak $56,7 \%$, dan masa kerja selama $>5$ tahun sebanyak 43,3\%.

Terdapat pengaruh pemahaman dokter tentang rekam medis, motivasi, sikap, imbalan, dan desain kerja terhadap kepatuhan dokter dalam pengisian rekam medis.

Tidak terdapat pengaruh pemahaman terhadap kepatuhan dokter dalam pengisian rekam medis.

Terdapat pengaruh motivasi terhadap kepatuhan dokter dalam pengisian rekam medis.

Tidak terdapat pengaruh sikap terhadap kepatuhan dokter dalam pengisian rekam medis.

Terdapat pengaruh imbalan terhadap kepatuhan dokter dalam pengisian rekam medis.

Tidak terdapat pengaruh desain kerja terhadap kepatuhan dokter dalam pengisian rekam medis.

Variabel yang paling mempengaruhi terhadap kepatuhan dokter dalam pengisian rekam medis adalah variabel motivasi.

\section{BIBLIOGRAFI}

Adiasa, N. (2013). Pengaruh Pemahaman Peraturan Pajak Terhadap Kepatuhan
Wajib Pajak Dengan Moderating Preferensi Risiko. Accounting Analysis Journal, 2(3). Google Scholar

Agustini, T., \& Mulya, C. A. (2019). Hubungan Motivasi Kerja Dan Imbalan Yang Di Terima Perawat Dalam Kepatuhan Pendokumentasian Flowsheet. Jikp Jurnal Ilmiah Kesehatan Pencerah, 8(01), 67-74. Google Scholar

Ahmad, M. H. (2020). Pengaruh Pengetahuan, Sikap Dan Motivasi Terhadap Kepatuhan Dokter Dalam Penulisan Diagnosis Pada Resume Medis Di Rs Zahirah 2018. Jurnal Administrasi Rumah Sakit Indonesia, 4(3). Google Scholar

Ahmadi, A. (2009). Psikologi Umum, Edisi Revisi 2009. Google Scholar

Anggraini, R., Arentze, T., \& Timmermans, H. (2007). Modeling Car Allocation Decisions In Automobile Deficient Households. Proceedings of The European Transport Conference (Etc) 2007 Held 17-19 October 2007, Leiden, The Netherlands. Google Scholar

Blass, T. (1999). The Milgram Paradigm After 35 Years: Some Things We Now Know About Obedience To Authority 1. Journal Of Applied Social Psychology, 29(5), 955-978. Google Scholar

Boeree, C. G. (2008). General Psychology. Jogjakarta: Prismasophie. Google Scholar

Dessler, G. (2004). Manajemen Sumber Daya Manusia, Edisi 9, Jilid 1. Jakarta: Kelompok Gramedia. Google Scholar

Dewi, N. R. (2015). Pengaruh Kemampuan, Motivasi, Dan Lingkungan Kerja Terhadap Kinerja Karyawan (Studi Pada Bmt Taruna Sejahtera). Iain Salatiga. Google Scholar

Engeser, S., Rheinberg, F., \& Möller, M. (2009). Achievement Motive Imagery In 
German Schoolbooks: A Pilot Study Testing Mcclelland's Hypothesis. Journal Of Research In Personality, 43(1), 110-113. Google Scholar

Gibson, M. (2008). Manajemen Sumber Daya Manusia. Cetakan Ke Dua. Jakarta: Erlangga. Google Scholar

Gufron, A., Mukhtar, M., \& Matin, M. (2018). Pengaruh Desain Kerja Dan Kepuasan Kerja Terhadap Produktivitas Pegawai Direktorat Pendidikan Diniyah Dan Pondok Pesantren Kementerian Agama Ri. Bina Manfaat Ilmu: Jurnal Pendidikan, 1(02), 66-73. Google Scholar

Huffman, E. K. (1994). Health Information Management. Google Scholar

Istirochah, I. (2021). Maternal Emergency: A Study Of Human Rights In A National Law Perspective. Journal Philosophy Of Law, 1(2), 98-103. Google Scholar

Lubis, S. (2018). Pola Komunikasi Personal Melalui Pendekatan Nilai-Nilai Islami Dalam Upaya Pencegahan Terhadap Perilaku Transgender. Network Media, 1(2). Google Scholar

Mangkunegara, A. A. A. P. (2005). Evaluasi Kinerja Sdm. Tiga Serangkai. Google Scholar

Mondy, R. W. (2008). Manajemen Sumber Daya Manusia Jilid 1. Google Scholar

Newman, J. M., \& Milkovich, G. T. (2008). Compensation. International Edition. New York: Mcgraw-Hill Co. Google Scholar

Nugroho, R. A. (2010). Sikap Dan Tindakan Masyarakat Pengendara Sepeda Motor Tentang Peraturan Lalu Lintas Menyalakan Lampu Utama Sepeda Motor Pada Siang Hari Di Wilayah Hukum Lalu Lintas Kartasura (Studi Deskriptif Kualitatif Mengenai Sikap Dan Tindakan Masyarakat Tentang Pera. Google Scholar
Pranoto, W. (2017). Solidaritas Sosial Masyarakat Besul Dalam Membentuk Kampung Berbasis Wisata Ekologi (Studi Kelurahan Temas Kota Batu). University Of Muhammadiyah Malang. Google Scholar

Rahayu, I. S., Karana, I., Hardiansyah, M. A., Dewi, D. H., \& Elihami, E. (2021). The Relationship Of Online Game Addiction With Learning Motivation In School Age Children On Covid-19 Pandemic. Linguistics And Culture Review, 5(1), 384-396. Google Scholar

Rahayu, N. D. (2015). Pengaruh Intellectual Capital Terhadap Kinerja Keuangan Perusahaan (Studi Pada Perusahaan Food And Bererages Yang Listing Di Bei Periode 2010-2013). Pengaruh Intellectual Capital Terhadap Kinerja Keuangan Perusahaan (Studi Pada Perusahaan Food And Bererages Yang Listing Di Bei Periode 20102013)/Ninda Dwi Rahayu. Google Scholar

Rakhmaningrum, K. (2016). Hubungan Motivasi Kerja Terhadap Kepatuhan Dalam Pengembalian Berkas Rekam Medis Di Seksi Rekam Medis Rumah Sakit Umum Daerah Dr. Soetomo. Jurnal Manajemen Kesehatan Yayasan Rs. Dr. Soetomo, 2(2), 153-162. Google Scholar

Robbins, M., Judge, A., \& Maclachlan, I. (2009). Sirna And Innate Immunity. Oligonucleotides, 19(2), 89-102. Google Scholar

Solikhah, S., Pamungkas, T. W., \& Marwati, T. (2010). Analisis Ketidaklengkapan Pengisian Berkas Rekam Medis Di Rumah Sakit Pku Muhammadiyah Yogyakarta. Kes Mas: Jurnal Fakultas Kesehatan Masyarakat Universitas Ahmad Daulan, 4(1), 24897. Google Scholar

Stephen, R. P., \& Timothy, J. A. (2014). Perilaku Organisasi, Edisi Keenam 
Belas. Jakarta: Salemba Empat. Google Scholar

Subkhi, A. (2012). Pengantar Manajemen Sumber Daya Manusia (Msdm). Google Scholar

Sugiyono, P. D. (2017). Metode Penelitian Bisnis: Pendekatan Kuantitatif, Kualitatif, Kombinasi, Dan R\&D. Penerbit Cv. Alfabeta: Bandung. Google Scholar

Tandy, D. Y. (2018). Analisis Kepatuhan Pengisian Berkas Rekam Medis Di Rumah Sakit Daerah (Rsd) Kalisat
Jember Tahun 2017. Google Scholar

Taylor, S. E., Peplau, L. A., \& Sears, D. O. (2009). Psikologi Sosial. Jakarta: Kencana Prenada Media Group. Google Scholar

Tutik, W. (2019). The Effect Of Job Satisfaction On Organizational Commitment And Work Discipline: A Study Of Foundation Permanent Lecturers In Stie Yapan Surabaya. Russian Journal Of Agricultural And Socio-Economic Sciences, 95(11). Google Scholar

\section{Copyright holder:}

M. Tryanza Maulana, Rokiah Kusumapradja, Andry (2022)

\section{First publication right:}

Jurnal Health Sains

This article is licensed under: 